\title{
Livestock value chain: Prediction of liveweight and cut yield of three indigenous breeds of cattle in Nigeria
}

\author{
${ }^{1}$ Babayemi, O. J., ${ }^{1}$ Ajayi, M. O., ${ }^{*}$ Olona, J. F., Anurudu, N. F. and ${ }^{3}$ Ajayi, F. T.
}

${ }^{\prime}$ Department of Animal Science, University of Ibadan, Nigeria $;{ }^{2}$ Federal College of Animal Health and Production Technology, Moor Plantation, Ibadan, Oyo State, Nigeria;

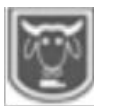

${ }^{3}$ Institute of Agricultural Research and Training, Moor plantation, Ibadan, Oyo State, Nigeria.

\section{Abstract}

*Corresponding author:jolona84@yahoo.com 08054228725

$\overline{\text { Problems associated with prediction of saleable meat yield, price haggling and monetary }}$ worth of cattle purchased due to difficulties in accurately relating visual appearance of animals and the weight with their price have always been in existence. This study was carried out to determine the accuracy in the use of heart girth tape as an alternative to the use of weighing bridge and crush, dressing percentage and expected cut yield from three indigenous breeds of cattle in Nigeria using linear body measurement. Thus, a total number of 51 healthy and mature White Fulani $(n=17)$, Sokoto Gudali $(n=17)$ and Red Bororo $(n=17)$ cattle breeds were randomly purchased from Ilesha Baruba cattle market Kwara State, Kotangora cattle market, Niger State and Akinyele cattle market, Ibadan, Oyo state and were subjected to heart girth measurements. The study lasted for 32 weeks. Live weights of animals were determined at the point of purchase using a specialized measuring tape (girth tape) calibrated in kilogram $(\mathrm{kg})$ and centimeter $(\mathrm{cm})$. The live weights were recorded in kilogram which was used in price negotiation at the market. The live weight of the cattle ranged from $164-463 \mathrm{~kg}$. The mean girth tape values were White Fulani $(286.53 \pm 51.06) \mathrm{kg}$, Sokoto Gudali $(293.35+77.51) \mathrm{kg}$ and Red Bororo $261.88+60.65) \mathrm{kg}$ respectively. Post slaughtering data collected were dressing percentage, weight of head $(\mathrm{kg}), n e c k(\mathrm{~kg})$, shanks( $\mathrm{kg})$, forearm $(\mathrm{kg})$, thigh $(\mathrm{kg})$, skin $(\mathrm{kg})$, liver $(\mathrm{kg})$, heart $(\mathrm{kg})$, intestine $(\mathrm{kg})$ and kidney $(g)$.The study revealed that heart girth measurement had high correlation coefficient with live weight $(r=0.99, p<0.001)$. This implies that the use of heart girth tape in weight prediction is accurate and reliable. There were significant $(p<0.05)$ differences in the dressing percentage among the breeds (43.55-46.52)\%. Significant $(p<0.05)$ differences were observed in the cut yield percentage between Red Bororo (33.16 \pm 4.12$)$ and other breeds but none between White Fulani (37.14 \pm 4.50$) \%$ and Sokoto Gudali $(34.53 \pm 5.26) \%$.There were significant $(p<0.05)$ differences in the head $(13.52-13.42) \mathrm{kg}$, Neck $(14.70-18.07) \mathrm{kg}$, left thigh $(27.92-29.41) \mathrm{kg}$, right forearm $(22.91-27.24) \mathrm{kg}$, left forearm (24.84-27.57) kg, liver (3.60-3.84) kg, skin (15.03-15.39), shank (2.20-2.41) kg, tail (5.23-5.92) kg but none for right thigh, kidney and lungs among the breeds. The variations in the yield may be as a result of genetic, management, weight and age of the animals. It can be concluded that heart girth tape may be used where weighing crush is not available because of its accuracy and reliability. The study also revealed that White Fulani has higher meat yield than Sokoto Gudali and Red Bororo and will therefore be more profitable to cattle sellers, abattoir centers, slaughter houses and meat shops.

Keywords: Liveweight, Cut Yield, Nigeria breeds of cattle, Linear Body Measurement

\section{Introduction}

The knowledge of livestock weight assessment remains the backbone on which all animal production management practices are hinged. Apart from avoiding the errors of visual determination of animal weights, small scale animal farmers need a simple skill and tool in estimating 
liveweight of cattle when a weighbridge cannot be assessed. Linear body measurements can be used to assess growth rate, feed utilization and carcass characteristics of farm animals (Brown et al. 1973). According to Birteebi and Ozoje (2012), when producers and buyers of livestock are able to relate animal measurements to carcass characteristics, optimum production and value based trading system will be realized. This would ensure that farmers and buyers get value for their stock and or livestock processors making a lot more profit rather than the middlemen (Afolayan et al., 2006). A weight band (heart girth tape) is a measuring tape whose graduation has a correlation between liveweight (measured in $\mathrm{kg}$ ) and linear measurement (measured in $\mathrm{cm}$ ). The weight band is a simple and portable yet practical and effective tool for livestock farmers without access to an appropriate weighing scale. Cattle marketing and processing is a source of livelihood to livestock farmers and butchers in Nigeria. Apart from taking live weight of meat animals, researchers also use body parameters such as body length and chest girths in other to adequately evaluate live animals. According to Srivastava et al. (1968), body measurements are indices of skeletal development and indirectly help to determine carcass composition.

Most cattle farmers, abattoirs and slaughter houses do not have access to a scale to weigh their livestock and this creates both management, purchasing and sales problems. In order to follow a standard way of weighing, it may then require that farmers have to travel long distances to weigh their livestock before selling or for management or for slaughtering. Embarking on such procedure would be cumbersome and unsustainable.

Marketing weights and estimation of animal's cash value, drug administration as well as conducting breeding studies, field experiments and estimation of dressed carcass weight are customary based on visual assessment (Msangi et al. 1999). This is mainly because the use of live weight criteria as recommended worldwide requires sophisticated facilities, weighing instruments but which are expensive, entails technical know-how and may be uneasy to transport. The agro-pastoral herder may be worst still due to their transhuman nature of cattle management and. At present, animal owners, veterinarians and cattle traders depend on visual assessment (eye ball judgment) to determine and estimate live weight. Apart from the fact that the outcome of visual appraisal of determining the liveweight of cattle might be subjective, the farmers might be producing at loss. Easier way but relatively accurate process for liveweight assessment should therefore be put in place. The objective of this study was therefore to determine the accuracy in the application of heart girth tape for liveweight prediction and the breed with highest cut yield among indigenous beef cattle in Nigeria.

\section{Materials and methods}

The study was carried out at the Slaughter House of the University of Ibadan. Hearth girth measuring tape, tape rule, digital/electronic weighing scale and table weighing scale were used for the study. The three indigenous breeds of cattle (White Fulani, Sokoto Gudali and Red Bororo) of varying ages of between 2-3 year using horn rings to determine age were sourced from Kwara, Niger and Oyo State respectively. A total of 51 cattle included 17 each was selected, purchased and used for the study. 


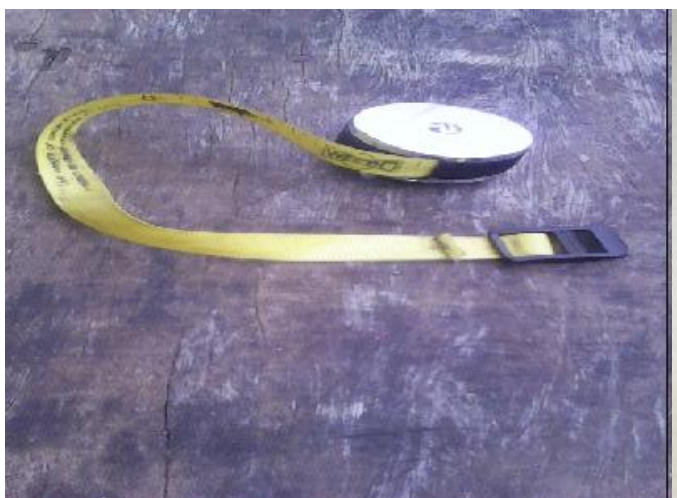

Plate 1: Heart girth tape

\section{Determination of live weight using heart girth tape}

At point of purchase, girth tape was used to estimate the liveweight of the animals.

The heartgirth was taken by the measurement of the circumference of the chest with the girth tape by placing the tape round the sternal region immediately after the forearm of the animal. Girth tape is calibrated in centimeter and kilogram; the weight was where the two ends met with the other side and these were recorded.

Slaughtering and processing of cattle

Prior to slaughtering process, the animals were kept in the lairage for 48 hours and served with feed and cool water. However, feed was withdrawn 12 hours before slaughtering. The cattle were slaughtered by severing the jugular vein and hoisted on the processing rail for 30 minutes for proper blood draining and collection of reverse peristaltic rumen ingesta to avoid carcass contamination. After lowering the carcass from the processing rail, it was flayed, and cut into quarters after the head and the limbs had been decapitated. Each part was weighed with the aid of a digital hanging scale to determine the dressing percentage and yield derivables. Dressing percentage was obtained as carcass weight by a percentage of liveweight. Carcass weight was estimated by: multiplying live weight by dressing percentage. It was e $\mathrm{x}$ pr essed mathematically as: Dressing percentage $=$
Plate 2: Hanging digital weighing scale

(carcass weight $\div$ live weight $) \times 100$

Carcass weight $=$ live weight $\times$ dressing percentage.

\section{Statistical analysis}

Data collected were subjected to one way analysis of variance procedure of SAS (1999). Significant means were separated using the Duncan multiple range test. The relationship of linear measurement and liveweight were estimated using general linear model. Regression technique was also used to obtain relationship between livebodyweight and heart girth for each breed groups.

\section{Results and discussion}

Table 1 show the mean values of heart girth and live body weight of the three indigenous breeds of cattle used in this study. The heart girth measurements and live weights ranged from $123-177 \mathrm{~cm}$ and $164-463 \mathrm{~kg}$ respectively. This is higher than those reported by Abdelhadi and Babiker (2009) for zebu cattle of South America (Solsa et al. 2002), zebu cattle of Australia (MacGowan et al. 2002) and Boran cattle of Ethiopia (Nicholas and Sayer, 1987). These differences might be due to genetic effect, environment and management practices. However, the mean weight in the present study is similar to that reported earlier by Mpiri et al. (1988). This implies that linear relationship existed between liveweight and heart girth. 
Livestock value chain: Prediction of liveweight and cut yield of three indigenous breeds of cattle in Nigeria

Table 1: Overall heart girth measurements and body weight of White Fulani, Sokoto Gudali and

\begin{tabular}{|c|c|c|c|c|c|}
\hline Breed of Cattle & $\begin{array}{l}\text { No. of } \\
\text { Animals }\end{array}$ & $\begin{array}{l}\text { Heart girth cm } \\
(\text { Mean+SD) }\end{array}$ & Range & $\begin{array}{l}\text { Weight kg } \\
(\text { Mean+SD) }\end{array}$ & Range \\
\hline White Fulani & 17 & $149.70 \pm 9.35$ & $128-171$ & $286.58 \pm 51.06$ & $183-418$ \\
\hline Sokoto Gudali & 17 & $153.88 \pm 14.79$ & $133-177$ & $293.35 \pm 77.51$ & $205-463$ \\
\hline Red Bororo & 17 & $146.00 \pm 12.71$ & $123-168$ & $261.88 \pm 60.65$ & 164-396 \\
\hline All animals & 51 & $149.84 \pm 12.66$ & $123-177$ & $289.59 \pm 69.51$ & $164-463$ \\
\hline
\end{tabular}

The results for carcass and cut yield from the three indigenous breeds studied are shown on Table 2 . There were significant $(\mathrm{p}<0.05)$ differences in the mean value obtained from the head $(\mathrm{kg})$, neck $(\mathrm{kg})$, left thigh $(\mathrm{kg})$, right forearm $(\mathrm{kg})$, left forearm $(\mathrm{kg})$, dressing percentage $(\%)$ and cut yield $(\%)$ among the three breeds. In all these parameters, White Fulani had the highest value over Sokoto Gudali and Red Bororo. The cut yield was $37.14 \%, 34.53 \%$ and $33.16 \%$ for White Fulani, Sokoto Gudali and Red Bororo respectively. However, there was variation in the dressing percentage; Red Bororo (45.42\%) had advantage over Sokoto Gudali (43.55\%). The value, $46.52 \%$ dressing percentage for White Fulani in this study does not agree with the earlier report by Tawah and Rege (1996) of 50-60\% dressing percentage. Right thigh was not significantly $(\mathrm{p}<0.05)$ different among the breeds statistically however, White Fulani (37.14\%) produced highest cut (meat) yield .These findings can be used to negotiate for the price of cattle in the market.

Table 2: Carcass and cut yield of three indigenous breed of cattle in Nigeria

\begin{tabular}{|c|c|c|c|c|}
\hline \multirow[t]{2}{*}{ Parameters } & \multicolumn{3}{|c|}{ Breeds of Cattle } & \multirow[b]{2}{*}{ SEM } \\
\hline & White Fulani & Sokoto Gudali & Red Bororo & \\
\hline Head(kg) & $15.42^{\mathrm{a}} \pm 2.62$ & $13.98^{\mathrm{b}} \pm 2.80$ & $13.52^{c}+2.53$ & 0.37 \\
\hline $\operatorname{Neck}(\mathrm{kg})$ & $18.07^{a} \pm 5.09$ & $16.48^{\mathrm{b}} \pm 6.72$ & $14.70^{c}+4.32$ & 0.77 \\
\hline Right Thigh(kg) & $30.06 \pm 4.85$ & $29.62 \pm 7.46$ & $27.17 \pm 6.14$ & 0.89 \\
\hline Left Thigh $(\mathrm{kg})$ & $29.41^{\bar{a}} \pm 5.89$ & $29.06^{\overline{\mathrm{b}}} \pm 7.70$ & $27.92^{-} \pm 6.06$ & 0.93 \\
\hline Right Forearm $(\mathrm{kg})$ & $27.24^{\mathrm{a}} \pm 5.41$ & $26.39^{\mathrm{b}} \pm 6.70$ & $22.91^{\mathrm{c}}+5.74$ & 0.86 \\
\hline Left Forearm $(\mathrm{kg})$ & $27.57^{a} \pm 5.68$ & $26.28^{\mathrm{b}} \pm 8.18$ & $24.84^{c} \pm 6.23$ & 0.94 \\
\hline Dressing Percentage (\%) & $46.52^{\mathrm{a}} \pm 3.31$ & $43.55^{\mathrm{c}} \pm 1.12$ & $45.42^{\mathrm{b}} \pm 3.59$ & 0.56 \\
\hline Cut yield $(\%)$ & $37.14^{\mathrm{a}} \pm 4.50$ & $34.53^{\mathrm{ab}} \pm 5.26$ & $33.16^{\mathrm{b}} \pm 4.12$ & 0.68 \\
\hline
\end{tabular}

abc Means with the same superscript are not significantly different $(p>0.005)$

Table 3 presents yield of internal and external offal of the three indigenous breeds of cattle. The values for the three breeds ranged from $0.64-0.78 \mathrm{~g}, 0.97-1.08 \mathrm{~kg}, 2.18$ $2.29 \mathrm{~kg}, 3.60-3.84 \mathrm{~kg}, 15.03-18.19 \mathrm{~kg}, 4.72-$ $5.61 \mathrm{~kg}, 3.30-2.41 \mathrm{~kg}$ and $5.23-5.92 \mathrm{~kg}$ for kidney, heart, lung, liver, skin, intestine, shank and tail respectively. The kidney, heart, lung and intestine of the three breeds showed no significant $(\mathrm{p}<0.05)$ differences.
The mean value of skin is higher in Sokoto Gudali(18.19) kg than White Fulani with higher dressing percentage. This corroborates the findings of Mohammed (2004) who reported that the yield of the external non-carcass components decline as the slaughter weight increases. Similarly, Eltahir, (2007) reported that total external and internal non-carcass components decreases with the increase in slaughter weight. 
Babayemi, Ajayi, Olona, Anurudu and Ajayi

Table 3: Yield of internal and external offal of three indigenous breeds of cattle in Nigeria

\begin{tabular}{|c|c|c|c|c|}
\hline \multirow[t]{2}{*}{ Parameters } & \multicolumn{4}{|c|}{ Breeds of Cattle } \\
\hline & White Fulani & Sokoto Gudali & Red Bororo & SEM \\
\hline Kidney(g) & $0.69 \pm 0.14$ & $0.78 \pm 0.29$ & $0.64 \pm 0.16$ & 0.90 \\
\hline Heart(kg) & $1.08 \pm 0.44$ & $1.03 \pm 0.51$ & $0.97 \pm 0.51$ & 0.07 \\
\hline Lung(kg) & $2.18 \pm 1.05$ & $2.26 \pm 0.85$ & $2.29 \pm 1.24$ & 0.15 \\
\hline Liver(kg) & $3.84^{\mathrm{a}} \pm 0.85$ & $3.78^{\mathrm{ab}}+1.15$ & $3.60^{\mathrm{b}} \pm 0.86$ & 0.13 \\
\hline Skin $(k g)$ & $15.39^{\mathrm{a} b} \pm 3.15$ & $18.19^{\mathrm{a}} \pm 4.46$ & $15.03^{\bar{b}}+4.86$ & 0.62 \\
\hline Intestine $(\mathrm{kg})$ & $5.61 \pm 1 . \overline{7} 0$ & $5.00 \pm 1.18$ & $4.72 \pm 1.58$ & 0.21 \\
\hline Shank(kg) & $2.41^{\bar{a}} \pm 0.60$ & $2.35^{\overline{\mathrm{b}}} \pm 0.78$ & $2.20^{\bar{c}}+0.62$ & 0.28 \\
\hline Tail(kg) & $5.67^{\mathrm{b}} \pm 0.99$ & $5.92^{\mathrm{a}}+1.06$ & $5.23^{c}+1.25$ & 0.16 \\
\hline
\end{tabular}

$\overline{\text { abc }}$ Means with the same superscript are not significantly different $(p>0.05)$

The correlation coefficients between liveweight and the heart girth measurements of all animals studied are shown in Table 4. All the correlation coefficients were significant. A higher positive correlation coefficient was found between live weight and heart girth in Sokoto Gudali $(r=0.99, \mathrm{P}<0.1)$ than in other breeds of cattle studied. This implies that there is high relationship between heart girth measurement and live body weight.

Table 4: Correlation coefficient between heart girth and live weight of three indigenous breeds of cattle in Nigeria

\begin{tabular}{lcc}
\hline Heart girth & Correlation coefficient & Level of significance \\
\hline White Fulani & 0.986 & $<0.0001$ \\
Sokoto Gudali & 0.991 & $<0.0001$ \\
Red Bororo & 0.989 & $<0.0001$ \\
\hline
\end{tabular}

\section{Conclusion}

The study showed that the use of heart girth tape in the prediction of liveweight is accurate and reliable; this tool is portable and convenient to be carried than heavy and expensive weighing bridge that might not even be available. The cut yield percentage were White Fulani > Sokoto Gudali > Red Bororo respectively. It is therefore, suggested that for optimum retail/profit maximization in slaughter houses and abattoir, White Fulani is the most appropriate breed for commercial purpose because of its high cut yield advantage over other breeds of cattle. This study if harnessed will assist cattle farmers/sellers, slaughter houses and meat shops in taking crucial managerial decisions especially on cut price and enhance bargaining potentials in the cattle market.

\section{Acknowledment}

The author(s) wished to acknowledge the support of the Slaughters House of the University of Ibadan for the provision of animals, materials and other logistics.

\section{References}

Abdelhadi, O. M. A. and Babiker, S. A. 2009. Prediction of zebu cattle live weight using live animal measurements. Livestock Research for Rural Development. Volume 21, Article No.133, 2010

Afolayan, R. A., Adeyinka, I. A. and Lakpini, C. A. M. 2006. The estimation of live weight from body measurements inYankasa sheep. Czech Journal of Animal Science 51: pp 343348

Atta, M. and El khidir, O. A. 2011. Use of heart girth, wither height and scapuloischial length for prediction of liveweight of Nilotic sheep. Small Ruminant Research 
55, pp 233-237

Birteebi, P. and Ozoje, M. O. 2012. Prediction of live body weight f r o m l i n e a $\mathrm{r}$ b o d y measurements of West African long-legged and West African dwarf sheep in Northern Ghana. Online Journal of Animal and Feed Research .Volume 2, Issue 5: pp 427-434

Blackmore, D. W., McGulliard, L. D. and Lush, J. L. 1995. Genetic relationship between body measurements at three ages in Holstein. Journal of Dairy Science 41: 1045

Bozkurt, Y. 2006. Prediction of body weight from body size measurements in Brown Swiss feedlot cattle fed under small-scale farming conditions. Journal of Applied Animal Research 29: pp 29-32

Brown, J. E., Brown C. J. and Butts, W. T. 1973. Evaluating relationships a $\mathrm{mong}$ i m ma t u re measures of size, shape and performance of beef bulls. Journal ofAnimal Science 36: $\quad$ 10101020

Buvanendran, V. and Olayiwola, $M$. B. 1983. Carcass characteristics of indigenous breeds of cattle in Nigeria. The Journal of Agricultural Science 100(02):407 $\begin{array}{llllll}4 & 1 & 1 & \mathrm{D} & \mathrm{O} & \mathrm{I}\end{array}$ 10.1017/S0021859600033566

de Villiers, J. F., Gcumisa, S. T. and Gumede, S. A. 2009. Estimation of live body weight from the heart girth measurement in KwaZuluNatal goats. Applied Animal Husbandry \& Rural Development 2009, Volume 2

Delhadi, O. M. A. and Babiker, S. A. 2009. Prediction of zebu cattle live weight using live Animal measurements. Livestock Research for Rural Development. Volume 21, Article No.133 May 1, 2010

Dingwell , R. T., Wallace, M. M ., McLaren L. C. F. and Leslie, K. K. E. 2006. An evaluation of two indirect methods of estimating body weight in Holstein calves and heifers. Journal of Dairy Science 89: pp 3992-3998

Eltahir, I. E. 2007. Growth and Development of Body Tissues and Characteristics of Major Muscles of Western Sudan Baggara Bulls. Ph. D. thesis Sudan A c a d e m y of S ciences, SAS, Animal Resources Research Council

Fajemilehin, O. K. S. and Salako, A. E. 2008. Body measurement characteristics of the West African Dwarf (WAD) goat in deciduous forest zone of Southwestern Nigeria. African Journal of Biotechnology 7,pp 2521-2526

Fida, M., Hamayun, K., Pervez., Muhammad, Z., Gul, N. and Rahimullah 2006. Relationship of body weight with linear body measurements in goats. Journal of Animal and Veterinary Advances 5, pp 452-455

Fouire, P. J., Neser, F. W. C., Oliver, J. J. and Van der Westhizen, C. 2002 . R e 1 a t i o n s h i p between production performance, visual appraisal and body measurements of young Dorper rams. South African Journal of Animal Science 32: pp 256-262

Goe, M. R., Alldredge, J. R. and Light, D. 2001. Use of heart girth to predict body weight of working 
oxen in the Ethiopian highlands. Livestock Production Science 69: pp 187- 195

Khan, H., Muhammad, F., Ahmad, R., Nawaz,G., Rahimullah, A. and Zubair, M. 2006. Relationship of body weight with linear body measurements in goats. Journal of Agricultural and Biological Science 1: pp 51-54

Kumar, A., Kebede, E. and Kassaye, E. 2010. Evaluation of quality of beef produced and sold in parts of Tigray Region of Ethiopia. Tropical Animal Health Production 42: pp 445-449

Kunene, N. W., Nesamvuni. A. E. and Nsahlai, I. V. 2009. Determination of prediction equations for estimating body weight of Zulu (Nguni) sheep. Small Ruminant Research 84, pp 41- 46

MacGowan, M. R., Bertran, J. D., Fordyce, G., Fitzpatrick, L. A., $\mathbf{M}$ i $\mathbf{l}$ l $\mathbf{e} \mathbf{r}, \quad \mathbf{R}$. G ., Jayawardhana, G. A., Doogan ,V. J., De Faveri , J. and Holroyd, R. G. 2002. Bull selection and use in northern Australia 1. Physical traits. Animal Reproduction Science 71: 25-37

Machebe, N. S. and Ezekwe, A. G. 2010.Predicting body weight of growing-finishing gilts raised in the tropics using linear body measurements. Asian Journal of experimental biological sciences 1:162-165

McGee, M. G., Keane, R., Neilan, A. P., Moloney. and P. J . Caffrey. 2007. Body and carcass measurements, carcass conformation and tissue distribution of high dairy genetic merit Holstein, standard dairy genetic merit Friesian and Charolais $\times$ Holstein-
Friesian male cattle. Irish Journal of Agricultural and Food Research. 46:pp 129-147

Mekonnen, H. M. and Biruk, T. 2004. Heart girth-body weight relationship in two Ethiopian zebu breeds. Revue de Medecine Veterinaire 155, pp 512-515

Mohammed, A. M. 2004. Effect of slaughter weight on meat potential o f W e s t e r n S u d a $n$ Baggara Cattle. Ph.D. Thesis, University of Khartoum

Mohammed, A. M., Atta, M., Babiker, S. A. and El Khidir, O. A. 2007. Economic evaluation of beef production from western Sudan Baggara bulls fattened to different slaughter weights. Sudan Academy of Science Journal, 1 (2): pp 19 29.

Msangi , B. S. J., Bryant, M. J., Kavana, P. Y. and Kizima, J. B. 1999.Body measurements as a management Tool for crossbred dairy cattle at a Smallholder farm condition. In; Proceedings of 26th Scientific Conference of Tanzania Society of animal Production (Edited by Mbaga et al) $3^{\text {rd }}-5^{\text {th }}$ August 1999, LITI - Tengeru, Arusha, Tanzania pp 168-175

Nesamvuni , A. E., Mulaudzi, J., Ramanyimi, N. D. and Taylor, G. J.2000.Estimation of body weight in Nguni type cattle under communal management conditions.South African Journal of Animal Sciences 30(1): 97-98

Northcutt, S. L., Wilson, D. E. and Willham, R. L. 1992. Adjusting w e i g h t f or b o d y condition score in Angus cows. Journal of Animal Science, (70):1342-1345

Nsoso, S. J., Aganga, A. A., Moganetsi, B. P. and Tshwenyane, S. $O$. 2003. Body weight, body condition 
Livestock value chain: Prediction of liveweight and cut yield of three indigenous breeds of cattle in Nigeria

score and heart girth in indigenous Tswana goats during the dry and wetseasons in southeast Botswana. Livestock Research for Rural Development 15 , article 5

Ojedapo, L. O., Adedeji, T. A., Olayeni, T. B., Adedeji, O. S., Abdullah, A. R. and Ojebiyi, O. O. 2007. Influence of age and sex on body weight and $\mathrm{s}$ o m e bo d y $1 \mathrm{i} \mathrm{n}$ e a $\mathrm{r}$ measurements of extensively reared West African Dwarf goats in $\mathrm{d}$ e $\mathrm{r}$ i v e d $\mathrm{s}$ a $\mathrm{v}$ a $\mathrm{n} \mathrm{n}$ a zone of Nigeria. Journal of Animal and Veterinary Advances 6, pp 114-117

Otoikhian, C. S. O., Otoikhian, A. M., Akporhuarho, O. P., Oyefia, V. E. and Isidahomen, C. E. 2008. Body measurement parameters as a function of assessing body weight in goats under On-farm research environment. African Journal of General Agriculture 4(3): pp 135140

Pesmen, G. and Yardimci, M. 2008. Estimating the live weight using s o m e b o d y measurements in Saanen goats. Archiva Zootechnica 11, pp 30-40

Purchas, W. 2003. Factors affecting carcass composition and beef quality. In D. C. Smeaton (Ed.) (Eds.). Profitable beef production: A guide to beef production in New Zealand (pp. 124-152). Wellington, NZ: New Zealand Beef Council. [Book - $\quad \mathrm{Chapter} \quad \mathrm{I}$, Research]. 2003

Riaño, A. L. and Saw, T. I. 2008. Evaluation of the behavior of yields in channel flesh, bone and fat of bovine commercial crossings participating in the Prime cattle competitions carried out in Colombia. Journal of Animal Science (1): 37-50

SAS (Statistical Analysis System) 1999. User's Guide Version 8.1. SAS Institute Inc., Cary, North Carolina, USA

Shirima, G. A., Kashoma, I. P. B., Kazwala, R. R. and $K$ a m b a r a g e, D. M . 2005. Estimating bodyweight of Tanzania Shorthorn Zebu (TSHZ) cattle using heart girth measurements. In: Proceedings of Tanzania Veterinary Association, Nov $14^{\text {th }}-$ $18^{\text {th }} 2005$, AICC, Arusha, Tanzania

Srivastar, K. K., Raizada, B. O. and Kulkarni, V. A. 1968. The an a tom of domestic animals.W B Saunders Company. Philadelphia.

Tawah, C. L. and Rege, J. E. O. 1996. White Fulani cattle of west and central Africa. Animal Genetic Resources Information Bulletin. 17:137-15

Thiruvenkadan, K. A. 2005. Determination of best-fitted regression model for estimation of body weight in Kanni Adu kids under farmer's management $\mathrm{s} \mathrm{y} \mathrm{s} \mathrm{t} \mathrm{e} \mathrm{m.} \mathrm{L} \mathrm{i} \mathrm{v} \mathrm{e} \mathrm{s} \mathrm{t} \mathrm{o} \mathrm{c} \mathrm{k}$ Research for Rural Development. Volume 17, Article No. 85

Williams, C. B., Keele, J. W. and Waldo, D. R. 1992. A computer model to predict empty body weight in cattle for diet and animal characteristic. Journal of Animal Science, 70:3215 - 3221

Received: $10^{\text {th }}$ November, 2017

Accepted: $21^{\text {st }}$ February, 2018 